\title{
CCL26 Gene
}

National Cancer Institute

\section{Source}

National Cancer Institute. CCL26 Gene. NCI Thesaurus. Code C24780.

This gene plays a role in chemotaxis and intercellular signal transduction. 